\title{
Equity Challenge Faced by Female Student with Regard to Access to FETC: Towards Realisation of FETC as Institutions of Choice
}

\author{
Jacob M Selesho \\ Faculty of Management Sciences. Vaal University of Technology. South Africa \\ E-mail:jmselesho@webmail.co.za
}

Doi:10.5901/mjss.2014.v5n2p135

\begin{abstract}
The paper examines access to Further Education Training College with regard to gender representation especially on SET related programmes. The paper reviews a diverse literature on gender access as well as financial support afforded to students in Further Education Training Colleges. Qualitative research approach was chosen with a specific focus on the survey research method. Data were collected from 90 college students enrolled for the first in 2012 academic year for various SET programmes. Gender inequality is more pronounced in some aspects of the educational systems than in others. The analysis distinguishes access to Further Education Training Colleges; access with regard to SET and financial implications. Female students fare relatively well in the area of access, less well in terms of the college experience, and are particularly disadvantaged with respect to the outcomes of schooling. Explanations of gender inequality in Further Education Training College should distinguish between these different aspects of education and should explain those contexts in which female have attained parity as well as those in which they continue to be less represented.
\end{abstract}

Keywords: Access, FET, Gender, Finance

\section{Introduction}

The Further Education and Training College (FETC) sector has evolved from the Technical College that primarily supported the apprenticeship system. The teaching directives of the former Technical colleges was to teach formal educational component for artisans in the major industries around South Africa, which include among other mining, electrical power, telecommunications and railway. In 1994, there were democratic elections in South Africa and that was followed by the scraping of the laws that segregated the South African Education system. Certain basic educational guarantees were founded. Hence, Chapter 2 of the Constitution of the Republic of South Africa states that: "...in terms of the international conventions ratified by Parliament, and in particular the right - (ii) of every person to basic education and equal access to education institutions"(Act 27,1996:100).

Enrolment in the FETC was restricted to mainly male and whites students particular those one that could not make it in formal secondary schooling system. For these selected groups FETC was an alternative educational sector to accommodate them, they used FETC as a route to substitute formal schooling. The green paper in post-school education (PSE) states clearly that the vision of department of high education (DoHeT) is to increase enrolment, with the intent of reducing the skills shortage that South Africa experience as a country (Green Paper for Post School Education and Training, 2012).

Based on the scenario stated above these paper intend to investigate access to FETC in response to the government mission.

\section{Enhancing Access to FETC}

Department of Higher Education in South Africa (2005:76) assented with flexible access to FETC throughout life and indicated that the government would strive to increase equitable access to existing FETC by raising the current level of enrolment by $20 \%$ in 2012, the government aim to increase enrolment by $60 \%$ in 2030. It is the concern of the government that FETC would be institutions of choice by 2030 (Green Paper for Post School Education and Training, 2012). This would be achieved through the construction of additional workshops and classrooms in existing institutions as part of the infrastructure development. With regard to equitable access, the government would take equity into consideration by encouraging female students to register in the so-called "hard" technical programmes such as 
engineering and related fields. Female students in particular blacks continue to be underrepresented and discriminated in sciences, engineering and commerce. In career related Inequality continues and discriminations continue to be (Green Paper for Post School Education and Training, 2012).

FETC are viewed to be institution of choice that has multiple but interrelated purposes: fulfil individual aspirations for self-development, supply the labour market with specialised skills, develop an enlightened, reflective and critical society and contribute to the creation, sharing and evaluation of knowledge (Al- Masci, 1999). In order to achieve the above outcomes, significant progress has been made towards increasing access to higher education, especially among previously disadvantaged populations. Promoting equity in post-school education is fundamental to creating a balanced society where all races have equal opportunity to participate in and contribute towards national social and economic development. However, despite government efforts, the post-education landscape remains inequitable (Green Paper for Post School Education and Training, 2012; Hwenha, 2013).

Trends in access and equity in post-school education aggregate enrolment in have increased by $69 \%$ from 528 135 in 1994 to 892936 in 2010. The major increase in enrolment has been at universities, where enrolment increased by 105\% (from 360250 in 1994 to 739368 in 2010). Enrolment in University of Technology decreased by 8\% (from 167885 in 1994 to 153168 in 2010). The number of previously disadvantaged people accessing post-school education has significantly increased at universities and universities of technology since 1995 (Green Paper for Post School Education and Training, 2012; Hwenha, 2013).

In many of these academic pathways, FETC play a critical role in enhancing students' transition to college from secondary education by preparing them to do college level work (Scheetz, 1996; Johanson \& Adams, 2003). For example, the National Vocational Qualification or the Nated programme offers students the opportunity to work towards: a) a National Diploma in a career area, b) a Trade certificate of $A$, and c) an associate's degree in a career area of the student's interest and ability. The targeted students are those who have left high school before graduation, are behind in high school credits, have at least an eighth grade reading level, live in a participating school district, or are willing to participate in a comprehensive high school completion program, which could potentially last for two or more years (Johanson \& Adams, 2003.

\section{Access to Further Education Training College}

Access was an issue that permeated in the White paper and Green paper on post school education. This issue was included in the White paper on trying to stimulate reform in this important sector of education. Southern Africa through Sub-regional Co-operation stated that demand for technical and vocational education and training places had been more greater than supply. Equal access and opportunity was deceptive because of inadequate facilities and equipment (UNESCO, 2000).

During the deliberations in the Sub-regional Co-operation forum matters concerning the existing infrastructure and programmes still needed to be improved in a number of ways to cope with the increased number of students. Barrett and Lally (1999) delineated that much of the demand lied not in urban areas, but in rural and remote areas where education and training facilities were under-resourced or non-existent as indicated. It is for this reason that matters concerning female student education were one concern, furthermore it was indicated that the equal opportunities philosophy, although written down, had been very difficult to implement (Eubanks, 2000).

Amidst concerns in public discourse about the vocational relevance of formal education and the employability of school leavers, there had been marginal growth in enrolment in vocational courses in local institutions (UNESCO, 2001) whereas some had opted for technical and vocational education and training (TVET) courses, very few school leavers had the requisite entrance requirements into these courses. It was also discovered that a very strong gender biases on enrolment still exist. Such treads had necessitated a review of policy in TVET to address issues of access, quality and relevance. The need for a demand driven provision of TVET, dictated that the private sector played a leading role in the development of TVET programmes (Tsiame 2008).

\section{Flexible Access to Technical and Vocational Education and Training throughout Life}

Regarding challenges and issues in flexible access to technical and vocational education and training throughout life, UNESCO (1997) substantiated that due to high cost of technical and vocational education the majority of those who could benefit from it because they did not have outstanding access to it. While considering access as results of gender, the study further reported on the financial aspect of the female students as an access matter (Tsiame, 2008). UNESCO 
further reported that the available technical and vocational education programmes were often de-linked from the production process and to a large extent were delivered using traditional theoretical methods. UNESCO added that technical and vocational education did not address the needs of the informal sector where most production activities went on (UNESCO, 1997).

The quality assurance programmes of certification had been other major challenges for technical and vocational education and training. There was a proliferation of certificated and diplomas ranging from short learning programme (SLP) to full qualification. This became difficult for employers to determine the worth as such credentialing resulting in under-employment in some cases existed (UNESCO, 2001).

UNESCO (2002) substantiated the need for appropriate skills in the discussions and recommendations on the flexible access to technical and vocational education and training throughout life were presented. The seminar proceedings substantiated that there was a need for clear government policies that gave priority to technical and vocational education and training by allocating appropriate funds for its execution.

Therefore, technical and vocational education and training systems must be designed to give life to this new paradigm in order to achieve flexible, innovation and productivity, imparting the skills required, addressing the implications of changing labour markets, training and retraining the employed, unemployed and the marginalized with the objective of achieving equality of opportunity for all in both the formal and informal sectors of the economy (UNESCO, 2001).

Lifelong learning, work and the future had been the journey with many pathways and technical and vocational education had been an integral part of the voyage. Therefore, in addition to UNESCO's reflection, technical and vocational education and training systems selection of didactic models should be apprehended and be designed as developmental life experiences with cultural and environmental aspects in addition to their economic dimensions (Johanson \& Adams, 2003).

Eubanks (2000) suggested that to make maximum contribution to lifelong technical and vocational education and training needed to be open, flexible and learner-oriented; they must do more than just provide the learner with knowledge and skills for specific jobs. It must also prepare individuals more generally for life and world of work (Bartman, Williams \& Lene, 2002). Technical and vocational education and training for personal, social and economic perspective and benefits should be utilised.

Technical and vocational education and training needed to be based on a learning culture shared by individuals, industry in different economic sectors and government. Individuals should be empowered to take progressively more responsibility for their own knowledge-management and independent learning while public and private provides ensured programmes that facilitated access to and through the pathways of lifelong learning (Bartman, Williams \& Lene, 2002).

\section{Methodological Procedures}

90 female students were selected to participate in the study from one FETC in the Free State Province of South Africa. The FETC were used because they formed what is known as recapitalisation of FETC. The study made use of purposive sampling comprising FETC that did not did not perform satisfactorily in their June results and adopted a utilisationfocused strategy that could assist the FETC to improve quality.

The data were collected from students of this selected college. Policy and legislation on access, as well as the FETC' policy provided the required data. Semi-structured focused interviews were conducted with HoDs and interviews with individual principals were done to collect data. We therefore analysed schools' performance in subjects in which students often have problems.

The data were analysed by identifying emerging themes, patterns and issues on the role of the HOD in access and financial support.

\section{Results and Findings}

Emerging themes, patterns and issues drawn from empirical data and from the literature are as follows: Access, financial assistance and parental financial whether they have influence on the student's admission.

Results and discussions have been organised in terms of themes and issues emerging from the questionnaire. Emerging themes and issues selected and discussed are as follow. 
Table 1: Student Population Responses on Gender Distribution in Programmes

\begin{tabular}{|l|c|c|c|c|}
\hline \multirow{2}{*}{} & \multicolumn{2}{|c|}{ More } & \multicolumn{2}{c|}{ Less } \\
\cline { 2 - 5 } & Count & $\%$ & Count & $\%$ \\
\hline Female students enrolment & 48 & $16.6 \%$ & 52 & $83.3 \%$ \\
\hline Female students enrolled in SET stream & 32 & $35.6 \%$ & 8 & $64.4 \%$ \\
\hline
\end{tabular}

Table 1 reveal that gender inequalities are evident in patterns of FET colleges' enrolment. While the numbers of female student enrolling at the FET Colleges are still a main concern, it is clearly evident that male students continue to dominate the sector particular in Science, Engineering and Technology at the FET Colleges

While in 2002 (Cosser cited Powell \& Hall, 2004) a total of $40 \%$ of students enrolled in colleges were female, by 2010 this figure had risen to $52 \%$ - which is exactly representative of the proportion of females in the general population. The implications of this shift at the systemic level are enormous: females are now fully represented in the college sector. However, this figure masks differences that may obtain at programmatic and course levels, not to mention at faculty $I$ department / school management levels. This college has a female population of $54 \%$ - thus meeting the requirements in terms of equity, redress and representivity. Transformation has occurred at the same rate as in other colleges provincially (Cosser, Netshitangani, Twalo, Rogers, Mokgatle, Mncwango, Juan, Taylor, Carel Garisch \& Marianne Spies, 2011).

FETC student's access to work based learning especially in SET related profession was also a challenge. Most students indicate the employers are hesitant in affording them the opportunity to participate in more male dominated profession experiential learning. The focus of experiential learning is to afford all students the opportunity to put into practice the theory that they have learn in their respective classes. However, challenge for exposure is important not only for enhancing teaching and learning, but also for enhancing access to meaningful employment, not only for a particular gender but for the whole college cohort. The data from the table above show the challenge that the college has demonstrated with regard to the importance of work integrated learning as one aspect that influence the gender representatives.

The table above paint a negative picture on the access of female student in the FETC sector, it can be concluded that the qualification type and the admission have not really focused on ensuring that female student are attracted in the profession.

Table 2: FET Colleges Student Population Responses with regard to Financial Assistance

\begin{tabular}{|l|c|c|}
\hline & Count & $\%$ \\
\hline Loan paying study fees (NFSAS) & 27 & $30 \%$ \\
\hline Parents paying study fees & 21 & $23 \%$ \\
\hline Employer paying study fees & 16 & $17 \%$ \\
\hline Bursary paying study fees & 11 & $12 \%$ \\
\hline Own finance to pay study fees & 15 & $16 \%$ \\
\hline Total & 90 & $100 \%$ \\
\hline
\end{tabular}

The government have established the National Student Financial Aid Scheme (NFSAS) in order to ensure that academically deserving students are supported to pursue their academic goals. From the Table 2 above it is clear that the post school education in South Africa depend entirely on the government contribution. From the total of 90 students surveyed $27(30 \%)$ are financially supported by NFSAS to pursue their academic goal. While $21(23 \%)$ of the students are supported by the families or parents, although the government is the biggest contributor in the FET sector, the study also noted the role played by the employer in funding their employees.

Majority of the respondents were really concern about few numbers of students that are supported financial by NFSAS as they felt that more students must be funded through this programme. The issue of NFSAS loan allocation as well as the criteria used and financial the academic programme supported need to be revised in order to be aligned with the South African Government priorities.

If compounded chi square value had been greater than the expected critical value 7.815 during the probability error; $p=0.05$ in the degree of freedom $\mathrm{df}=3$. Then, as accorded the existence of the significance relationship between financial determined access to FET college qualification. It can be depicted from the table that financial assistance was an influencing factor in ensuring that the student enrol for the envisaged qualification. Financial assistance articulated access to FETC enrolment. 
Table 3: Responses with regard to students' financial assistance (chi square)

\begin{tabular}{|l|c|c|c|c|c|c|c|}
\hline \multirow{2}{*}{$\begin{array}{l}\text { Is there any financial assistance that students } \\
\text { are getting to pursue their studies at LP? }\end{array}$} & \multicolumn{3}{|c|}{ Yes } & \multicolumn{3}{|c|}{ No } & \multirow{2}{*}{ Totals } \\
\cline { 2 - 9 } & & & & & & & \\
\hline Students & 41 & 29.10 & 4.87 & 3 & 8.83 & 3.85 & 44 \\
\hline Totals & 211 & & & 64 & & & 319 \\
\hline
\end{tabular}

The success rate of the FETC Colleges is the lowest among the post school sector in South Africa. The national benchmark success rate was approximate $80 \%$ and the university targeted a $73 \%$ success rate in 2013 . The throughput rate was $14 \%$ as compared to the national benchmark of $25 \%$. Academic performance in terms of teaching output was poor. Although the colleges have tried to introduce the NCV as a development programme to ensure that the articulation and more skills orientated programmes are offered, this system have not yielded positive result. The university had a foundation learning and development programme that provided opportunities for students from disadvantaged backgrounds to access higher education.

The inadequate student pass rate of the university was affected by various factors such as under-preparedness, poor financial backgrounds and other social challenges.

\section{Conclusion}

Although access to post school sector with regard to gender in certain programme is still a challenge, the study can report that the overall access to post-school sector have increased significantly over the past couple years. The gender and financial implications were found to be the most contributors with regard to access in FET College. Female student were less represent in certain field of specialisation within the FET College fraternity. The gender difference were highly visible even though when looking at the institutional enrolment there were some balances, but the disparities as stated were observed in the SET programmes.

The only means to support student financially in the post school sector were through NFSAS and very few seta. The study did reveal that the bursary mechanism were not enough for this sector.

Transforming today's post-school education institutions into world-class institutions has challenged top-level managers to address the need for what the World Bank's higher education - described as three complementary sets of factors: a high concentration of talent, abundant resources and favourable governance. Transformation of the post school education system into a four-year state college system necessitates the expansion of facilities to provide opportunities for the increasing number of students expected to enrol, as well as the need for continual re-evaluation and enrichment of courses and curricula to suit the needs of students and the community.

\section{References}

AI- Masci M: 1999: vocational Education and the changing Demand of the world of Work. UNESCO. Asia-Pacific Region

Bartman J, Williams J. and Lene P. 2002: Formative evaluation of a project increasing access to TVET in the Pacific Region through the Use of Open and Distance Learning. The Pan_Commonwealth Forum on Open Learning. Durban, South Africa.

Barrett, E and Lally, V 1999: Gender differences in an online learning environment. Journal of Computed Assisted Learning 15(4): 4860.

Cosser M, Netshitangani T, Twalo T, Rogers S, Mokgatle G, Mncwango B, Juan A, Taylor V, Garisch C and Spies M 2011: Northern Cape: Rural FET College. Report prepared for the Department of Higher Education and Training. South Africa.

Eubanks, V 2000. Paradigms and perversions: A woman's place in cyberspace. PCSR newsletter, 18(2):1.

Hwenha S, 2013. First Rand Report: Increasing access and support to tertiary education: Lesson learned from CSI-funded bursary programmes in South Africa.

Green Paper for Post School Education and Training, 2012; Policy Directive For South African Government Printers. Pretoria.

Johanson KR and Adams A 2003: skills Development in Sub-Sahara Africa. The World Bank, Washington, DC.

UNESCO 1997: Studies in Technical and Vocational Education International Project on Technical and Vocational Education. UNESCO, France.

UNESCO 2000: The Dakar Framework for action. Education for all: meeting our collective Commitments. Adapted by the World Education Forum, Dakar.

UNESCO; 2001: Updated Version of the Revised Recommendation Concerning Technical And Vocational Education: Proposal By The Director. UNESCO General Conference. Paris.

UNESCO 2002: Technical and Vocational Education and Training for the Twenty-first Century.

UNESCO, France. 
Scheetz, L. P. 1996. Recruiting Trends 1995 - 1996. A study of 527 Businesses, Industries, and Governmental Agencies Employing New College Graduates. Washington DC: Collegiate Employment Research Institute.

Tsiame, C 2008. The role of creation of employement through the use of TVET. Central University of Technology, Unpublished M.Tech Dissertation.

Ziderman, A.; 1997: Journal of Vocational Education and Training; National Programmes in Technical and Vocational Education: Economic and Educational Relationships, 49 (3): 147.

Ziderman A. 2003. MINISTRY OF Education and Training Development of Technical and Vocational Education and Training: Technical and Vocational Education and Training Policy Studies. 